The University of Maine

\title{
DigitalCommons@UMaine
}

School of Economics Faculty Scholarship

School of Economics

Spring 1974

\section{From National Populism to National Corporatism: The Case of Bolivia (1952-1970)}

Melvin Burke

University of Maine

James M. Malloy

Follow this and additional works at: https://digitalcommons.library.umaine.edu/eco_facpub

Part of the Economics Commons, Latin American Studies Commons, and the Oil, Gas, and Mineral Law Commons

\section{Repository Citation}

Burke, Melvin and Malloy, James M., "From National Populism to National Corporatism: The Case of Bolivia (1952-1970)" (1974). School of Economics Faculty Scholarship. 11.

https://digitalcommons.library.umaine.edu/eco_facpub/11 


\author{
MELVIN BURKE \\ University of Maine \\ JAMES M. MALLOY \\ University of Pittsburgh
}

Tn the wake of the depression of 1929 there sprung up 1 throughout Latin America a number of reformist political movements which today are generally lumped under the term National Populist Movements (Di Tella, 1965). Among the best known of these movements were Alianza Popular Revolucionaria Americana (APRA) in Peru, Acción Democrática (AD) in Venezuela, and Movimiento Nacionalista Revolucionario (MNR) in Bolivia. These movements projected themselves as sui generis Latin phenomena which would solve the problems of economic development and social justice in Latin America in a unique "national" way-neither socialist nor capitalist. While the programs of these movements varied somewhat (often reflecting their different histories), there was and remains a central core of national populist ideology and orientation.

Stripped to its essentials, the national populist ideology projected two major goals: (1) to break the traditional dependence of the local economy on the industrial centers of the United States and Europe, e.g., antiimperialism; and (2) to destroy local semifeudal structures, such as the latifundia, so as to liberate human and material resources for state-sponsored development. These two goals were embedded in a diagnosis which argued that national problems were not the result of class exploitation but rather the exploitation of the nation (middle classes, workers and peasants) by the antination (the local oligarchy and the imperial foreign interests it served). To resolve this problem, they argued, a broad multiclass movement-as opposed to a class-based partyhad to be formed to seize power from the local oligarchy, break its hold on the economy, and assert national economic as well as political independence of the imperialist powers.

Although oriented toward the mobilization of workers and peasants, these movements were mainly supported and led by 
elements of the dependent urban middle sectors (e.g., those who lived off salaries and fees). The middle-class intellectual elites who organized these movements saw themselves as paladins called upon to lead their backward countries, and the culturally underdeveloped workers and peasants that inhabited them, to the fulfillment of their respective national destinies. ${ }^{1}$ They would do so by seizing the state and utilizing it to regulate the society and economy so as to achieve economic development and social justice. Despite the fears these movements generated among established interests, their programs were hardly revolutionary, calling rather for substantial, but hardly total, reform imposed from above. The political history of all these movements clearly shows that the core orientation of the so-called populist elites was reformist, elitist and statist.

In this paper we seek to analyze the experience of one Latin American nation, Bolivia, which has been undergoing an experiment in a "populist" resolution of her socioeconomic problems since 1952. We shall focus primarily on the decade of the 1960 s, when after eight years of tortuous veering along a number of policy paths, a clear model of development began to emerge.

The model of development which emerged in Bolivia during the 1960 s can best be termed national corporatism: a system of political economy that attempts to achieve controlled economic growth by fusing traditional hispanic concepts of state control with modern corporate organizations in both the public and private sectors. National corporatism is an authoritarian and statist approach to development that results in an elitist and hierarchical mode of social organization, which from the point of view of most in the lower social orders is often repressive and at best paternalistic. Ironically, the so-called populist approach, due to a number of factors delineated below, evolves into a system of political economy which is decidedly antipopular. The Bolivian case is not unique but a manifestation of a general trend toward authoritarian solutions to development evident in a number of Latin American states. An analysis of the Bolivian case can shed light on the general trend and contribute specific insights into what to expect from other so-called populist regimes such as the populist military government of neighboring Peru.

Bolivia: 1952-1964

In 1964 the MNR, which initiated the Bolivian National 
Revolution of 1952, was overthrown in a military coup backed by large segments of the populace including workers and peasants. The coup did not represent a counterrevolution so much as a ratification by arms of the failure of the MNR to achieve the revolutionary goals it had set for Bolivia.

The failure of the MNR to achieve its revolutionary goals can be traced to a number of factors endemic to the contemporary developmental situation and to the nature of populist coalitions themselves. The first is a contradiction between the strategic political goal of mobilizing the middle class, workers and peasants by playing upon the pent-up demands of these groups for increased standards of living, and the strategic economic goal of rapid development. In the underdeveloped situation the economic goal demands internal economies by restricting consumption, but the political goal of the populists demands the mobilization of support by meeting the consumptionist desires of the popular masses.

Between 1952 and 1956 the MNR elite tried to meet both goals at once and followed a dual policy of investment and consumption. During this period the Left, backed by workers' militias, was dominant and Bolivia was headed in a populist and essentially socialist direction. However, the dual policy sent the state mining corporation (COMIBOL) into a tailspin, created severe balance of payments problems, and set off wild inflation that fell most heavily on the urban middle class, thereby turning that group against the revolution.

These problems brought home three inescapable facts: (a) an underdeveloped country cannot follow a course of economic development and popular consumption at the same time; (b) any process of restructuring for development demands that some social groupings must pay the social costs of the new course; and (c) the populist premise of a community of interests among the middle class, workers and peasants flies in the face of the reality of the underdeveloped situation. There is of necessity a conflict of interests among such diverse groupings: first over the distribution of rewards but latterly over the even more divisive issue of the distribution of the social costs of any developmental strategy. Facing the scarcity of the underdeveloped situation, the populist movement that comes to power immediately confronts a dual problem: (1) the contradiction between economic and political goals; and (2) the conflict of interests among its support groups. 
Any consistent model of development requires that the government be in a position to restrict consumption in the name of development and that it choose which of its own support groups gain and which lose.

In confronting these difficult problems, the MNR found itself with an additional problem, namely the need to secure external financial support to supplement Bolivia's meager resources. In Bolivia the decision was made to reject the socialist bloc as a source of aid (at that stage there is serious question as to whether the Soviet Union wanted or could afford to accept the burden) and rely almost exclusively on the capitalist states. On one hand, the decision reflected the need to bow to the realities of the dependent nature of an underdeveloped economy; on the other, it reflected the long-standing determination of not only the MNR elite but other populist elites as well to stay firmly within the western camp. The Bolivian case supports the view that populist antiimperialism boils down to less a question of breaking the ties that bind Latin America to the United States and Europe, than to rearranging them in a way that hopefully benefits the local dependent country (Cotler, 1970-71). In any event, once the decision was made the previous questions of benefit and loss were already decided.

This became clear in 1956 when in order to secure International Monetary Fund (IMF) financing, the MNR accepted a monetary stabilization program which reversed the previous thrust of the revolution (Eder, 1968: 626). It did so by stopping the expansion of the public sector, reintroducing market principles, and shifting costs onto labor by freezing wages and withdrawing food subsidies. When labor responded negatively, the MNR set out to break its political power by rebuilding the military as a counterweight to workers' militias and by turning the major peasant organizations against the communist-inspired labor movement. During this period the Bolivian National Revolution was going through a major change of gears brought on by internal and external constraints. The major factors were: (a) the basic reformist orientation of the old-guard MNR elite; (b) the contradiction between economic and political logics in an environment of extreme scarcity and high mobilization; (c) the internal contradictions of the multiclass populist movement itself; (d) the price tag affixed to much needed external financing. By 
1960 the populist phase of the revolution was over and the groundwork was laid for the national corporate phase which was to follow.

This new mode of political economy was broadened and more clearly defined after 1960 within the context of the Alliance for Progress strategy accepted by the MNR. Particularly under the Triangular Plan ${ }^{2}$ for the rehabilitation of the tin iridustry, labor was kept on the defensive and the MNR instituted a concerted effort to break its political power once and for all. Through the "civic action" logic central to the Alliance, President Paz Estenssoro sought to solidify the military-peasant alliance and with U.S. help turned the military into the key group in the situation. ${ }^{3}$ During this period the organized private sector of the economy made a startling comeback, the position of COMIBOL stabilized and Bolivia began to register growth rates of over 5 percent per year. Despite these apparent economic successes, internal divisions in the MNR and social protest brought on by President Paz's policies so weakened the credibility of the MNR that it was a surprisingly simple task for the military to topple the government in November $1964 .^{4}$

The Generals and the Revolution:

The Consolidation of National Corporatism

From November 1964 to August 1966, Bolivia was governed by a military cabinet with first General René Barrientos alone, and later (in May) he and General Alfredo Ovando together acting as chief executive. In 1966 Barrientos waged a successful electoral campaign and in August was inaugurated as constitutional president. Ovando assumed the position of commander-in-chief of the armed forces. Throughout this period both stressed that their administration did not constitute a counterrevolution but a true realization of the national populist revolution originally promised by the MNR but betrayed by capricious men such as Paz.

The new government immediately looked to the United States as a major source of aid and, after a brief period of indecision, the United States supported the generals. Indeed many in the American Embassy argued that only the military had the will and 
capacity to maintain stability, promote enterprise and achieve planned rates of economic growth.

The coup of 1964 , changed little from the point of view of political economy. The new regime followed, but more effectively, the same game plail formulated by Paz and his U.S. advisers in the previous four years (Thorn, 1971: 199). Under Barrientos and Ovando, Bolivia moved definitively and rather ruthlessly in the national corporatist direction. Under the new law for the promotion of investment passed in October 1965, private investment rose from $\$ 3$ million in 1963-64 to $\$ 47$ million in 1966. Gulf Oil investments increased from an annual average of $\$ 6,991,706$ (1957-63) to an average of $\$ 16,742,475$ (1965-68). New mining laws also spurred private investment and parts of the state's mining activities were denationalized. ${ }^{5}$ The Matilde zinc mine, for example, was sold to a U.S. combine of U.S. Steel and the Philips brothers. In addition, private contract mining was reintroduced into the state mining operation and many laid-off miners were obliged to work for these contractors without the labor code's protection. The resurgence of the private sector in mining and petroleum is evident in Table 1.

Table 1 Private and Public Production of

Crude Oil and Minerals (1963-1968)

\begin{tabular}{|c|c|c|c|c|}
\hline & $\begin{array}{r}\mathrm{Cl} \\
(000\end{array}$ & $\begin{array}{l}\text { OIL } \\
\text { meters) }\end{array}$ & & $\begin{array}{l}\text { ALS* } \\
\text { ric tons) }\end{array}$ \\
\hline & $\begin{array}{l}\text { Private } \\
\text { (Gulf) }\end{array}$ & $\begin{array}{l}\text { Public } \\
\text { (Y.P.F.B.) }\end{array}$ & Private & $\begin{array}{c}\text { Public } \\
\text { (COMIBOL) }\end{array}$ \\
\hline 1963 & 18.5 & 501.6 & 27.0 & 26.0 \\
\hline 1964 & 15.2 & 498.0 & 35.0 & 28.0 \\
\hline 1965 & 2.3 & 528.2 & 35.0 & 27.0 \\
\hline 1966 & 458.6 & 504.5 & 43.0 & 33.0 \\
\hline 1967 & $1,872.0$ & 435.1 & 47.0 & 32.0 \\
\hline 1968 & $1,886.2$ & 497.4 & $48.3 \dagger$ & $34.5 \dagger$ \\
\hline
\end{tabular}

Private corporate activity once again dominated mining which accounted for 85 percent of Bolivia's export earnings and petroleum, the nation's fastest growing industry. While there is no precise serial data on rates of private investment in other 
industries, Table 2 shows that by 1968 the overall Bolivian economy was dominated by the private sector. Private corporate activity had truly made a comeback in the 1960 s.

Table 2 Gross Domestic Product and Employment Broken Down by Private and Public Sector Contributions (1968)

\begin{tabular}{|c|c|c|c|c|c|c|}
\hline & \multicolumn{3}{|c|}{ Gross Domestic Prod.* } & \multicolumn{3}{|c|}{ Employment } \\
\hline & & & & & (\%) & $(\%)$ \\
\hline & Total & Public & Private & Total & Public & Private \\
\hline Agriculture & 1,224 & 05 & 95 & 897 & 05 & 95 \\
\hline Mining & 457 & 55 & 45 & 54 & 45 & 55 \\
\hline Petroleum & 435 & 20 & 20 & 07 & 65 & 35 \\
\hline Manufacturing \& energy & 773 & 25 & 75 & 104 & 25 & 75 \\
\hline Construction & 346 & 30 & 70 & 122 & 30 & 70 \\
\hline Commerce \& finance & 619 & 05 & 95 & 98 & 05 & 95 \\
\hline Transportation & 417 & 05 & 95 & 58 & 05 & 95 \\
\hline Government & 475 & 100 & 00 & 58 & 100 & 00 \\
\hline Other services & 500 & 20 & 80 & 167 & 20 & 80 \\
\hline Total & 5,245 & 25 & 75 & 1,567 & 15 & 85 \\
\hline
\end{tabular}

*In millions of pesos at 1958 prices.

†In thousands.

Source: Burke (1970).

Bolivia's public corporations were not neglected by the Barrientos government. During the years 1965-68, ENDE (the national electic power company), LAB (the national airlines) and other Bolivian public corporations received substantial assistance from both the Bolivian government and foreign lenders. LAB alone began receiving the first dispersion of an $\$ 18$ million loan package in 1968 negotiated by the Barrientos government. The nationalized railroads obtained credits from Japan totaling $\$ 10$ million in 1966 for capital equipment. In addition, the third phase of the Triangular Plan to rehabilitate COMIBOL was agreed upon in the summer of 1965 after the Bolivian government sent the army to the mines to "discipline" (destroy) the labor unions and to "rationalize" (reduce) the labor force. Under this agreement, COMIBOL received credits totaling $\$ 10$ million to be expended by 1968. As a result of this economic policy, the major public corporations of Bolivia in the aggregate began to realize economic profits for the first time in their history.

When the proposed tin smelter, gas pipeline, fertilizer plant and other public investments are added to the above, the evidence 
supporting the contention that the Barrientos government pursued an economic policy of promoting large-scale private and public corporate units is substantial. The gas pipeline alone necessitated an investment of $\$ 46$ million jointly financed by Gulf Oil Company and the World Bank. The private and public corporations of Bolivia are similar in more ways than they differ. Both are autonomous, profit-maximizing and growth-oriented enterprises.

Table 3 Profit and Loss* Positions of the Major Public Enterprises

(\$ millions)

$\begin{array}{ccccc}\text { Year } & \text { COMIBOL } & \text { Y.P.F.B. } & \text { Railroads } & \text { Total } \\ 1964 & -4.1 & 1.1 & -3.1 & -6.2 \\ 1965 & 0.3 & 1.4 & -1.3 & 0.4 \\ 1966 & 2.0 & 2.6 & -1.3 & 3.3 \\ 1967 & 1.1 & 3.6 & -0.7 & 4.0 \\ 1968 & 1.2 & 4.0 & -1.3 \dagger & 3.9 \\ 1964-68 & 0.5 & 12.7 & -7.8 & 5.4\end{array}$

*Loss (-); profit (+)

†USAID estimates.

Source: USAID (1969a).

If Bolivia were not an underdeveloped country, none of this behavior on the part of the Barrientos government would seem worthy of mention, let alone analysis. However, Bolivia is an underdeveloped country with a large traditional sector which this national corporate policy discriminates against. Nowhere is this more evident than in agriculture.

\section{Traditionalism}

In Table 2 agriculture is seen to engage more people in production than any other sector, yet agriculture was the only major Bolivian industry that experienced virtually no growth during 1964-68 as seen in Table 4. In addition, it is estimated that the majority of the Bolivian labor force engaged in agricultural production accounted for only 20 percent of the gross domestic output in 1968.

How does one explain this lack of growth in the agricultural sector when the avowed goal of the Bolivian development plan is to diversify the economy, to substitute domestic food production for imports and to raise the standard of living (Ministerio de 
Planificación, 1962)? Agriculture, unlike mining, aviation and the other sectors, is dominated by nonmodern units of production best described as traditional peasant farms. Largely because of this, agricultural production was assigned a low priority by the Barrientos government. In addition, it was the modern corporate segment of agriculture which received the bulk of the technical assistance and financial support allocated.

Table 4 Index of Gross Domestic Product Increases by Sector in Constant 1958 Prices $(1963=100)$

$\begin{array}{lcccccc} & 1963 & 1964 & 1965 & 1966 & 1967 & 1968 \\ \text { Agriculture } & 100 & 1.02 & 1.05 & 1.06 & 0.99 & 1.03 \\ \text { Mining } & 100 & 1.08 & 1.09 & 1.18 & 1.24 & 1.27 \\ \text { Petroleum } & 100 & 1.06 & 2.12 & 1.56 & 2.69 & 2.84 \\ \text { Manufacturing \& energy } & 100 & 1.09 & 1.20 & 1.32 & 1.40 & 1.49 \\ \text { Construction } & 100 & 1.02 & 1.28 & 1.42 & 1.75 & 2.01 \\ \text { Commerce \& finance } & 100 & 1.04 & 1.08 & 1.11 & 1.14 & 1.20 \\ \text { Transportation } & 100 & 1.05 & 1.09 & 1.13 & 1.19 & 1.24 \\ \text { Government services } & 100 & 1.14 & 1.15 & 1.26 & 1.28 & 1.32 \\ \text { Other services } & 100 & 1.12 & 1.14 & 1.18 & 1.11 & 1.29 \\ \quad \text { Total } & 100 & 1.05 & 1.11 & 1.18 & 1.24 & 1.31\end{array}$

Source: Ministerio de Planificación (1969).

Because the latifundia of prerevolutionary Bolivia were inefficient, backward and stagnant, they were expropriated in 1953 and the land redistributed to the peasants. ${ }^{6}$ The governments of Bolivia have since been faced with a dilemma inasmuch as the new land tenure system is also predominantly nonmodern in structure. This may explain why the Bolivian governments have not yet legally entitled all the land obtained by the peasants under the agrarian reform law. Only about 25 percent of the agricultural land censused in 1950 was redistributed to the peasants by 1968 . In addition, the Barrientos government during 1964-68 granted an annual average of 16,119 titles as compared with an annual average of 40,095 titles issued during the previous five years (Servicio Nacional de Reforma Agraria, Departamento de Estadísticas). One explanation for the small amount of land titled since 1953 is the fact that the large estates in the lowlands were not affected by the reform. These lowland estates now constitute the new corporate sector of Bolivian agriculture.

As can be seen in Table 5 below, Bolivia spends the same amount of foreign exchange on food and related agricultural 
imports today as it did before the agrarian reform of 1953. In 1967, \$22.4 million of milk, wheat flour and edible oil were imported, all of which could have been produced in Bolivia.

Table 5 Value of Imports by Type

( $\$$ millions)

$\begin{array}{lcccc}\text { Food, Beverages, } & \begin{array}{c}\text { Mfg. } \\ \text { Tobacco \& Live } \\ \text { Animals }\end{array} & \begin{array}{c}\text { Raw } \\ \text { Materials }\end{array} & \begin{array}{c}\text { Capital } \\ \text { Goods }\end{array} & \begin{array}{c}\text { Other } \\ \text { Mfg. } \\ \text { Goods }\end{array} \\ 1952 & 27.8 & 10.8 & 15.5 & 38.5 \\ 1954 & 23.1 & 9.8 & 11.8 & 20.8 \\ 1956 & 21.5 & 7.2 & 27.2 & 28.1 \\ 1958 & 15.5 & 4.7 & 24.6 & 34.8 \\ 1960 & 13.9 & 5.9 & 26.6 & 25.1 \\ 1962 & 20.5 & 15.1 & 30.0 & 31.3 \\ 1964 & 18.3 & 15.5 & 31.2 & 37.7 \\ 1966 & 25.7 & 24.8 & 49.2 & 38.7 \\ 1967 & 30.9 & 26.2 & 54.0 & 39.9 \\ & & & & \\ \text { Principal Imports } & & 1960 & 1965 & 1967 \\ \text { Milk } & & 1.5 & 2.4 & 2.8 \\ \text { Wheat flour } & & 6.1 & 12.2 & 14.1 \\ \text { Greases and edible oils } & - & 5.4 & 5.5 \\ \text { Machinery } & & 15.0 & 21.5 & 31.7 \\ \text { Vehicles } & & 5.7 & 16.0 & 21.6 \\ \text { Iron and steel } & & - & 14.8 & 12.1\end{array}$

Source: USAID (1969a).

That Bolivia can efficiently and economically produce her own wheat, edible oil, milk and other foods is no longer seriously questioned. Why then does she not allocate the necessary investment funds to the task? For example, it is estimated that the Barrientos government annually allotted only 3 percent of its budget to agriculture. In addition, nearly all of these investment funds were received and spent by the corporate agriculture sector in the lowlands of Santa Cruz and the Beni. Consequently, the methods of production and level of technology in the highlands and valleys has remained virtually unchanged since the time of the Incas. Community development is the largest single project in the traditional rural sector and its major efforts are directed to improving health and education. It is therefore not surprising to find that the production of such traditional crops as potatoes, 
corn and wheat remained stagnant or decreased from 1964 to $1968 .^{7}$ On the other hand, the increase in rice, sugar and beef was due to large public investments supporting private corporate activity in the lowlands.

Table 6 Indices of Selected Agricultural Products* $(1963=100)$

$\begin{array}{lcccccc}\text { Year } & \begin{array}{c}\text { Peeled } \\ \text { Rice }\end{array} & \begin{array}{c}\text { Refined } \\ \text { Sugar }\end{array} & \text { Beef } & \text { Potatoes } & \begin{array}{c}\text { Corn } \\ \text { (Grain) }\end{array} & \text { Wheat } \\ 1964 & 1.25 & 1.36 & 1.04 & 100 & 100 & 104 \\ 1965 & 1.32 & 1.25 & 1.31 & 105 & 92 & 64 \\ 1966 & 1.38 & 1.18 & 1.51 & 107 & 93 & 75 \\ 1967 & 1.37 & 1.39 & 1.49 & 102 & 86 & 49 \\ 1968 & 1.81 & 1.58 & 1.63 \dagger & 102 \dagger & 84 & 82\end{array}$

* Original data in thousands of metric tons with the exception of beef which is in heads of cattle slaughtered.

†USAID estimates.

Source: USAID (1969a).

For example, over $\$ 100$ million has been invested in roads, colonization and related projects in the lowlands. All of this has indirectly benefited the corporate farmers in these regions. More specifically, cattle production in the Beni has made rapid progress due to past loans from IDA, AID and the government of Bolivia. In 1968, the Agricultural Bank began negotiating a $\$ 23$ million loan with the World Bank and the Inter-American Development Bank to finance beef cattle production. More recently, the Cattlemen's Association of the Beni signed a contract with COMIBOL to supply the entire nationalized mines' beef requirements. Originally these past investments were intended to make Bolivia self-sufficient in beef. Later, however, the goal was changed to promote exportation.

A similar situation existed in rice and sugar production. In 1967 and 1968 alone rice farmers received over $\$ 1$ million in economic assistance from USAID. These loans, too, were predominantly made to large commercial producers and millers like Grace, Hansa and others. The resultant industrial concentration reached the point where 3 percent of the rice farmers in three Santa Cruz provinces produced over 30 percent of the area output on farms averaging better than 100 hectares. Today, Bolivia is self-sufficient in rice and sugar and no one can deny that the increase in the 
output of these products was the result of these large investments in agricultural machinery, sugar and rice mills, etc.

Both foreign lenders and the Bolivian government constantly cite the production record of these few products as examples of the tremendous strides being made in agriculture. Nowhere, however, does one encounter an admission that such impressive returns were accompanied by a large opportunity cost. What, for example, would the returns have been had these millions been invested in the traditional sector of Bolivian agriculture? Perhaps Bolivia would not now be spending approximately $\$ 14$ million annually of her scarce foreign exchange on imported wheat and flour (an amount, incidentally, vastly greater than the total value of the entire Bolivian rice and sugar production). It is paradoxical that the local currency generated from PL480 wheat flour sales was used to build roads, promote colonization and increase production of rice, sugar and cattle in the lowlands-that is, do everything except increase the production of wheat (Burke, 1971). In short, the peasant agriculturalists were discriminated against in Bolivia during the 1960 s and because of this the agricultural sector stagnated.

The reluctance and/or inability of the Barrientos government to deal with the small, competitive, noncorporate producers was also evident in the retailing service and artisan sectors. In every case the result was the same: production stagnant, productivity low and technology backward because little or no investment funds were made available to these producers.

Stabilization and Growth

Nationally, a very conservative monetary and fiscal policy was adhered to by the Barrientos government. It is only fair to point out that AID, IMF and other organizations made fiscal and monetary restraint conditional to aid. The result of the Bolivian government's pursuit of stable prices was increased government budget deficits and an enormous foreign debt.

The major instrument responsible for the restricted credit expansion and overall spending in the Bolivian economy from 1964 to 1968 was the annual IMF-Bolivian standby agreements. ${ }^{8}$ The purpose of these agreements was to improve the balance of payments by restricting credit expansion and spending in the 
economy-thereby improving public finances while maintaining reasonable price stability and economic growth. Table 7 reveals the amount and extent of these agreed upon credit restrictions from 1965 to 1968 .

Table 7 Credit and Spending Limitations of Recent IMF-Bolivian Standby Agreements (\$b. millions)

Subject to Ceilings

Overall monetary system

Central government (GOB)

Public corporations

Counterpart accounts

Private sector

$\begin{array}{ccr}1965 & 1966 & 1967 \\ 122 & 161 & 109 \\ 116 & 110 & 60 \\ - & - & 3 \\ -6 & 40 & 40 \\ - & 11 & 6\end{array}$

1968

193.6

125.6

47.9

59.4

$-39.3$

Note: These figures are only approximations since the standby agreements are not available to the general public. In addition, the time period of the agreements vary. The 1968 agreements lasted, for example, thirteen and one-half months.

Source: Banco Central de Bolivia, Departamento Monetario.

By more or less adhering to these controls, apparent price stability was achieved. The Bolivian peso remained at 11,885 to the U.S. dollar, foreign exchange reserves increased from $\$ 21.3$ million in 1964 to $\$ 32.4$ million in $1968,,^{9}$ and inflation was at least contained as seen in Table 8 below.

As indicated by the data, these nonselective monetary restraints were no panacea for Bolivia's economic problems. On the contrary, there is every reason to believe that the tight monetary policy, at least in part, contributed to these very same problems.

The stable exchange rate, while it has its merits, was almost considered sacrosanct by the Bolivian authorities. However, because Bolivia's trading partners continually devalued their currencies over this time period, it follows that if the Bolivian peso was optimally related to the currencies of her trading partners in 1959-with the exception of the United States and Germany-it is highly unlikely that the peso remains today in the same optimum relationship. ${ }^{\circ}$ Not only did the stable fixed exchange rate do nothing to induce export earnings or retard import expenditures, it was also ineffective in stimulating foreign investments or reinvestment of foreign profits earned in Bolivia. Net private foreign investment decreased by $\$ 12.5$ million (mainly Gulf Oil Company investments) in 1965 to an estimated minus $\$ 2.8$ million in $1968 .{ }^{11}$ During the same time period, net investment income 
Table 8 Balance of Payments, Central Government Total Budget, Increases in Foreign Debt, Rate of Inflation and Rate of Real Economic Growth (1964-1968)

GOB budget*

(\$b. millions)

$$
\begin{array}{lllll}
1964 & 1965 & 1966 & 1967 & 1968
\end{array}
$$

$\begin{array}{lllll}-95.0 & -228.5 & -224.8 & -445.7 & -477.2\end{array}$

Increases in $\mathrm{GOB}$

foreign debt

(\$ U.S. millions)

$\begin{array}{lllll}12.1 & 14.2 & 7.9 \dagger & 22.0 & 37.6\end{array}$

Balance of payments*

(\$ U.S. millions)

$17.6 \quad 14.2$

$3.2-9.0$

0.6

Rate of inflation

(La Paz)

10.2

2.9

$6.9 \quad 11.2$

5.5

Rate of growth

(GDP in constant prices)

$4.8-5.6$

5.6

6.5

7.2

Per capita GSP in constant prices

$2.4 \quad 3.4$

*Deficit (-); surplus (+)

† \$9 million in interest to Eximbank forgiven.

Source: USAID (1969a).

leaving the country increased from $\$ 1$ million to $\$ 10.5$ million. U.S. grants to Bolivia also decreased from $\$ 18.4$ million in 1964 to $\$ 3.5$ million in $1968 . .^{12}$ The only thing which saved Bolivia from experiencing a complete disaster in her international accounts in 1967 and 1968 was the compensating increase in foreign loans to the central government and her public corporations from $\$ 14.2$ million in 1964 to $\$ 52.0$ million in 1968 .

Ultimately, these tremendous increases in central government capital expenditures to compensate for the decreased foreign investment expenditures and U.S. grants resulted in large budget deficits and tremendous increases in the nation's foreign debt. ${ }^{13}$

Although private domestic investments increased during 1964-68, these too were severely handicapped by the credit restrictions inasmuch as they were instrumental in exhausting the excess reserves of the private banking system. ${ }^{14}$

Fortunately, increased savings were forthcoming to finance much of the new domestic investment spending. Bank demand 
deposits grew from $\$ b .142 .4$ million in 1964 to $\$ b .282 .9$ in 1968 , bank savings deposits from $\$ b .98 .2$ to $\$ b .264 .8$, and the portion of total loans to the private sector from 26 percent in 1963 to 50 percent in 1968 (USAID, 1969a).

In summary, the tight money policy of the Barrientos government can hardly be considered an unequivocal success. True, price stability was obtained which in turn encouraged an increase in domestic savings and investment during 1964-68. However, the tight credit restrictions prevented domestic investments (both private and public) from increasing in sufficient quantity to offset the decrease in U.S. grants and foreign investment. In addition, virtually the entire flow of investments from all sources was allocated to large public and private corporations or to social overhead capital projects like roads. Stable prices, while serving the Bolivian corporate interests in the short run, may well have been self-defeating inasmuch as the nation's budget remained unbalanced, the foreign debt increased and the people's aspirations for a higher standard of living were scarcely satisfied.

Table 9 Reserves of the Private Banking System

(\$b. millions)

$\begin{array}{cccc}\text { Total } & \text { Legal } \\ \text { Reserves } & \text { Reserves } & \text { Excess } \\ 1964 & 60.5 & 48.4 & \begin{array}{c}\text { Reserves } \\ 1965\end{array} \\ 1966 & 97.9 & 63.0 & 12.1 \\ 1967 & 104.6 & 84.2 & 24.9 \\ 1968 & 116.8 & 96.9 & 20.4 \\ & 120.6 & 122.0 & 19.9 \\ & & 1.4\end{array}$

Source: Superintendencia de Bancos, Boletines Mensuales.

These last statements are thinly veiled implications that the Barrientos government sacrificed growth for price stability. There is no way of knowing what would have been the effect upon prices, output, etc., had the government seen fit to pursue some alternative policy. Although Bolivia's real growth rate over these years is rather impressive, especially when contrasted with those of previous years, one cannot but suspect that a much greater increase in real output could have been obtained at very little cost. For example, a greater expansion of credit would undoubtedly 
have resulted in increased domestic private investment in light of the great demand for loanable funds. That such an expansion of domestic credit would inevitably contribute to inflation is doubtful. ${ }^{15}$ Likewise, a policy of allocating a small amount of investment funds to the noncorporate sector of the economy in quick payoff projects such as flour import substitution (instead of high-cost, long-term payoff infrastructure projects) would have reaped very large and immediate benefits for the Bolivian economy. It is impossible to imagine Bolivia attaining anything approximating self-sustaining growth unless the traditional sector is integrated into the country's market economy.

\section{Nationalism}

There are various other ways in which national corporatism manifested itself throughout the years of the Barrientos administration. Institutions and activities which create, expand or strengthen nationalism prospered from 1964 to 1968. Foremost among these institutions was public education. Approximately 33 percent of the central government's budget appropriations in 1968 went to education; half of the school population received Food for Peace assistance; and a bewildering number of education and human resource studies have been made. ${ }^{16}$ The World Bank, IDB, UNESCO, UNICEF and similar organizations had numerous projects in operation and expressed a willingness to invest even more in the area.

All this is eminently logical since public education is an indispensable building block of nationalism. Education as a mechanism of national integration is a particularly crucial question in a racially diverse country such as Bolivia where over 60 percent of the population is both racially and culturally Indian. One could argue that the effort in public education, whatever its presumed benefit for the Indian masses, was also an attempt by the dominant mestizo and white groups to control the Indian majority by "integrating" them into the extant creole culture. Education is also a field considered to lie within the public domain by the United States and other western donors, which qualifies it for massive aid. These huge expenditures of funds and effort could not, however, raise the Bolivian literacy rate above an estimated 60 percent of the population by 1968 . This is more indicative of 
the magnitude of the problem than the lack of commitment on the part of the government and others. Education is one of the few noncorporate institutions that can look forward to continued support from the national corporate establishment of Bolivia.

Road construction was another activity vigorously promoted by the Barrientos government. The central government's highway expenditures, exclusive of foreign grants and loans, averaged approximately $\$ 5$ million annually from 1964 to 1968 . Roads, like education, are generally considered to lie within the public domain and received more foreign assistance than any other project. USAID alone invested over $\$ 75$ million in roads since 1961 and presently has approximately $\$ 68$ million in the road construction pipeline. ${ }^{17}$ Typically, road construction is justified on the grounds that it promotes colonization and ultimately increases agricultural production. The poor performance of the entire agricultural sector, however, belies the elaborate and expensive cost-benefit studies which attempt to economically justify road projects. Roads are favored over other projects because of the attempt to integrate the culturally diverse and geographically dispersed segments of Bolivian society and thus serve the national corporate state. Again, the modest gains in this field, as measured by the 15,500 miles of roads in all of Bolivia, indicate no lack of commitment on the part of the national corporate governments. However, there exists abundant evidence of the unplanned, inefficient and unproductive nature of Bolivia's transportation development. ${ }^{18}$

Finally, no respectable national corporate structure would be complete without a strong military. The Barrientos government increased its expenditures on military outlays from $\$ b .71 .7$ million in 1964 to $\$$ b. 160.9 million in 1968 , or by more than 100 percent. This was the largest percentage increase in central government expenditures on current account over this time period (IMF, 1967-68). The obvious reason Bolivia maintains approximately 20,000 men in the armed forces is to police the nation, i.e., "maintain law and order." The absence of armor, combat aircraft, etc., belies any claim to protecting national sovereignty. The multimillion dollar military assistance supplied by the United States is, in effect, counterrevolutionary political assistance. In AID jargon, part of this support is designated "public safety" assistance. Politics and the military in Bolivia are inextricably 
intertwined, and therefore the military, like education and road construction, can look forward to continued support and close association with the national corporate state.

From an economic point of view, these vast expenditures on education, roads and the military at this stage of Bolivia's development can hardly be justified. Aside from the military expenditures which need little explanation, the other two are high-cost, long-term investments in infrastructure of questionable payoff. They are major contributors to the current government budget deficits, balance of payments deficits and foreign debt. They appear to be classic examples of the type of misallocation of resources one encounters in this type of system.

\section{The Social Effects of the Policy}

Whatever the long-range economic merits of the Barrientos program, it was in the short run a period of prosperity for some. The healthy private sector gave birth to an incipient new upper class of entrepreneurs, speculators and high level managers. The urban middle class benefited from the expansion of middle-level public and private jobs, rising salaries and a stable currency. As the data above indicated, the single largest institution to benefit was the Bolivian military. Aside from the limited hard data available, the new prosperity of the middle and incipient upper classes was more than obvious in the proliferation of high rise apartments, posh restaurants, boutiques, fashionable clothing, night clubs, etc. (see date on construction boom in Table 4).

The cost of this new prosperity was borne mainly by the popular masses, i.e., workers, urban marginals and peasants; the hardest hit were workers and in particular miners. Although labor supported the overthrow of Paz, it was soon to learn that the thrust against its position went deeper than the policy preference of a single individual. In the spring of 1965, the Barrientos government issued a series of labor decrees aimed at bringing the unions under control. In the mines there were massive layoffs, salaries were cut in half (from roughly $\$ 1.60$ a day to $\$ 0.80$ a day) and there were reductions in subsidized store privileges. ${ }^{19}$ When the miners reacted (May 1965), the military invaded the mines, smashed the strike and disarmed the militias. When the remainder 
of organized labor protested, the military moved against the entire movement killing or exiling leaders and submitted what was left of the once powerful unions to strict governmental control. In September 1965 and June 1967 the military again entered the mines by force and put the major mines under permanent occupation. With the possible exception of oil workers, Bolivian laborers experienced a relative decline in living standards during the Barrientos period, primarily because they were forced to live on fixed or reduced wages in an economy that was running an inflation of approximately 6 percent a year. Although some new jobs were created, especially in construction, they were more than offset by rural-urban migration which held down wages, reduced employment security and dramatically increased the urban marginal population of the unemployed and underemployed.

From a political point of view the Indian peasantry, in terms of publicity at least, was the most courted group in the nation. Utilizing a helicopter, Barrientos traveled widely in the countryside donning a poncho here, mounting a mule there, and embracing peasants everywhere.

On each stop he demonstrated his largess by dedicating a school, promising potable water or distributing soccer balls and uniforms to the children. He became the patron of all the peasants-a personalized symbol of he from whom all good things would personally flow. Throughout the countryside, towns and villages vied for his personal attention by naming everything from the town hall to the local bridge after him.

Whatever went into the countryside was localized and personalistic. The operative logic appeared to be that wherever the peasants were politically sophisticated and their leaders loyal, they gained; where they were politically marginal or their support in question, they were either ignored or punished. In certain regions the unions were squashed and old landowners and townsmen made a political comeback (Research Institute ..., 1969: 180-206). The apparent universal peasant support of Barrientos was in fact pockets of peasant support with rewards doled out accordingly. A good deal of the money spent in the countryside went to buy peasant leaders. As the data above indicated, the Indian peasantry as a whole gained little, and relative to other groups actually lost. Barrientos courted the peasants through the classic demagogic means of highly visible activity with large political payoffs but 
with little substantial material benefit in terms of growth or increased living standards.

To most outside observers, especially those hospitable to his policies, the Barrientos regime was considered a resounding success story. In this paper we have tried to show that from the points of view of long-range economic growth and social justice, that judgment is dubious. From the point of view of building viable civil and political institutions his tenure was also mixed. From the beginning, the regime suffered from two critical structural weaknesses: (1) it had no political organizational base; and (2) it excluded the major political organizations of the country. Aside from the few pockets of peasant support, Barrientos relied primarily on the military to keep him in power.

As civilian opposition to his regime mounted in 1968-69 (led by the excluded parties, labor and students), Barrientos's standing with the military decreased sharply. Although a couple of attempted coups failed, the signs increasingly pointed to a military takeover. Before the drama could be played out, however, Barrientos was killed on April 27, 1969 when his helicopter crashed after a trip to a peasant village.

After a brief and confused civil interregnum the military emerged again in September 1970 to assume open control of the government. From September 1970 to August 1971, Bolivia, first under General Alfredo Ovando and then General José Torres, appeared to move sharply away from national corporatism. In August 1971, however, the military backed by the MNR and its old enemy the Falange Socialista Boliviana (FSB) threw Torres out and announced an end to his "leftist madness." Now marching in tandem the military and the MNR are putting Bolivia firmly back on the national corporate track.

\section{Conclusion}

The national corporatist style of political economy that emerged in Bolivia during the 1960s is a logical outcome of the national populist approach to problems of development. A number of factors operate to lead to this outcome. One is the clash between the imperatives of the elite's developmental aims (investment) and the demands of the supporters of the movement (consumption) in an environment of scarcity. This clash is exacerbated by the 
multiclass nature of the national populist movement and the inevitable conflict of interests among its supporters once such a movement achieves formal power. The result is the thorny problem of how to allocate rewards and more importantly, costs, within any developmental strategy. In confronting this problem two factors become crucial: the fundamental orientation of the national populist elite and the realities of the international situation. The orientation of these elites is fundamentally middle-class, elitist and reformist. This orientation becomes critical when the elite seeks to decide how to relate to international actors.

While populism is rhetorically nationalistic and antiimperialistic, the elites of these movements, in this case the MNR, have rejected the eastern socialist bloc as a major source of aid and therefore, in the long run, were forced to remain dependent on western capitalist powers for needed external financing. As we have seen, aid through instrumentalities such as the IMF, etc., carries strings which limit options on how to deal with social costs and therefore has profound political repercussions. Thus the middle-class orientation of the populist elite and the realities of external financing combine to create a reality wherein the situation of dependence is modified but by no means eliminated. The populist approach is heavily statist (thereby swelling the number of bureaucratic positions) but in no way socialist. Populism attacks the so-called feudal past and dependence in the name of a new form of dependence and a technocratic form of state capitalism which we call national corporatism.

The concept of national corporatism is still crude and needs refinement. Our tentative view of how the ideal-typical national corporatist system operates is as follows. Control in the system is in the hands of a complex new elite of economic and political entrepreneurs, technocrats, bureaucrats and often top labor leaders. In Bolivia, labor was excluded because: (a) the unions controlled important industries, e.g., mining, which had to be "reformed"; and (b) the unions were led by leaders who rejected the corporate model. In other countries, e.g., Mexico, highly organized unions led by "cooperative" leaders have of ten obtained "a piece of the action," thereby dividing the labor movement into favored and unfavored segments. The power of the new elites rests on an alliance of powerful corporate interests in the public and 
private sectors coordinated by an agglomerated party or, as has recently been the case in Peru and Bolivia, by a nationalist oriented military. Through such coordination, the state or public sector seeks to "regulate" the private sector so that its activities redound to national economic growth. The distribution of jobs and income is accomplished through bargaining in a nationally regulated market with those highly organized groups capable of deploying political or economic power holding the upper hand. Hence, the bulk of the costs tends to fall on noncorporate interests such as peasants, urban marginals and the less wellorganized workers. These allocations are often backed by force in cases of protest-for example, the Bolivian army's occupation of the mines in 1965 and 1967. National corporatism as an economic philosophy differs from the more orthodox philosophies of socialism or capitalism. National corporatism as the name implies, favors nationally owned enterprises and is at least rhetorically antiimperialistic. While national corporate governments are willing to nationalize foreign holdings, such actions are not based on a philosophy that favors public over private property. These nationalizations are always presented as specific actions against specific companies for their specific antinational sins. While some foreign holdings are taken over and often certain sectors put off limits to outsiders, foreign investment as such is not rejected but in fact encouraged. National corporate governments attempt to control such investment and seek better terms for the country, but often their ability to bargain is constrained by international economic realities.

With respect to productive property, national corporatism is indifferent as to public or private domestic ownership. However, because few governmental officials themselves are indifferent to the issue of public versus private ownership, they tend, at any given time, to favor one or the other. The long-run result of this continual oscillation is compromise, i.e., a mixed economy. Lastly, national corporatism promotes corporations over other forms of business enterprise. Autonomous corporations, both public and private, are viewed as dynamic, efficient, modern institutions which will ensure the economic development of the nation and a higher standard of living for its people. Small peasant farms, cooperatives, artisans, and other noncorporate producers are tolerated, but never enthusiastically supported. 
It is our hope that this exploration in the development of national corporatism in Bolivia will aid in the understanding of the changes taking place in other Latin American nations, particularly those where national popular movements have achieved some measure of power. Moreover, we hope it gives a base for anticipating the emergence of general lines of political economy in other nations which choose the national popular approach. Specifically we have in mind Peru which is presently engaged in an experiment in military populism. Our anticipation is that when all is said and done military populism in Peru will result in a system that is a variation on the theme of national corporatism.

\section{NOTES}

1. The following statement of the MNR leader Victor Paz Estenssoro (1955: 316-17) is a good example: "It is a general law that the men of the oppressed class are never the ones who achieve gains for their own class, and this for a simple reason: those of the oppressed class do not have the economic means to even raise themselves culturally and develop their personality, let alone be able to make a great reform or a revolution ..."

2. The Plan involved a pledge of $\$ 37$ million to refurbish COMIBOL by the U.S. government, the Federal Republic of Germany and the Inter-American Development Bank. In return Bolivia was to "rationalize" its labor policies primarily by submitting unions to managerial discipline, holding the line on wages and laying off excess workers. The plan was to cause a major confrontation between the MNR and labor.

3. U.S. military aid to Bolivia was resumed in 1958 and climbed from $\$ 0.1$ million in 1958 to $\$ 3.2$ million in 1964 . During this period the military regained its traditional control function and assumed important developmental tasks as well. As relations between the MNR and labor deteriorated the military moved into the pivot of the political situation. For data on military and economic aid see Blasier (1971: 77).

4. For a more detailed analysis of the 1952-64 period see Malloy (1970) and Malloy and Thorn (1971).

5. These include Supreme Decrees Nos. 7148, 7447 and 7360 of 1965.

6. A Bolivian highland latifundium was a large agricultural operation which utilized great quantities of land and labor combined with little capital other than breeding livestock. They were usually absentee-owned and run on traditional rather than profit-maximizing principles.

7. Many observers become confused when they consider the multitude of projects in the traditional sector of Bolivian agriculture with their meager results. But the Peace Corps, community development and the like are no substitutes for massive investments in production. 
8. These standby agreements are arrangements between the IMF and individual countries whereby the Fund furnishes the country with international reserves (gold, dollars, etc.) in excess of its "drawing rights" provided it undertakes certain corrective measures to balance its international accounts. A country has drawing rights to 25 percent of its IMF quota; Bolivia's IMF quota is $\$ 25$ million; therefore, she has drawing rights to $\$ 7.25$ million. Bolivia has entered into eleven standby agreements with the Fund, the last one for $\$ 20$ million became effective January 16,1969 , which will run for approximately one year.

9. However, $\$ 12.4$ million of these 1968 total reserves were IMF reserves as opposed to $\$ 5.5$ million of the 1965 total reserves (USAID, 1969b).

10. Only the U.S. dollar remained in a fixed relationship with the Bolivian peso. Great Britain devalued her currency by 15 percent since 1964. Argentina by 167 percent, Brazil by 213 percent, Chile by 129 percent and Peru by 60 percent.

11. The minus figure is explained by depreciation charges exceeding investment expenditures.

12. The decrease in grants was a unilateral decision on the part of the United States. Bolivia could only accept it.

13. U.S. grants to the central government decreased from \$b. 93.5 million in 1964 to $\$$ b. 10.6 million in 1968, while central government capital expenditures increased from $\$$ b. 160.5 million in 1964 to $\$$ b. 473.9 million in 1968 . The central government's total budget deficit in 1964 was \$b. 95 million and in 1968 it was an estimated \$b. 477.2 million (IMF, 1967-68).

14. This unusual situation of the existence of temporary negative excess reserves was the result of SD No. 08576 of November 16, 1968, which raised the legal reserve requirement on demand deposits from 35 percent to 40 percent and on savings deposits from 25 percent to 30 percent. Shortly thereafter, however, the banks were able to adjust.

15. The only statistics on inflation in the La Paz price index (in addition to being somewhat unreliable) only represent about 10 percent of the Bolivian population and not a representative 10 percent at that. Further, these credit restrictions themselves have contributed to higher interest charges and higher procurement prices for the government, which because of the central bank credit ceiling imposed upon it by the IMF Bolivian standby agreements was forced to buy with nonnegotiable IOUs at higher prices.

16. To name just a few, there is the Ohio State University Resource Survey, a School Building Survey and a Vocational Education Survey all financed by USAID/La Paz.

17. The fact that virtually all road construction was undertaken by U.S. contractors undoubtedly made it a politically acceptable AID venture.

18. The UN/IBRD Global Transportation Study exposes a greater deal of the unplanned, inefficient and politically oriented Bolivian road program. This perhaps explains why the Bolivian government has not yet seen fit to release the study to the general public.

19. The labor force in COMIBOL mines was decreased from 25,225 workers in 1964 to 20,917 in 1968. 


\section{REFERENCES}

BLASIER, COLE

1971 "The United States and the Revolution." In Malloy and Thorn (eds.), Beyond the Revolution: Bolivia Since 1952. Pittsburgh: University of BURKE, MELVIN Pittsburgh Press.

1970 "El sector privado en la economía boliviana y la necesidad de crédito." Estudios Andinos 1: 117.

1971 "Does Food for Peace Assistance Damage the Bolivian Economy?" Inter-American Economic Affairs 25: 3-26.

COTLER, JULIO

1970-71 "Political Crisis and Military Populism in Peru." Studies in Comparative International Development 6 (no.5): 95-113.

DI TELLA, TORCUATO

1965 "Populism and Reform in Latin America." In Claudio Véliz (ed.), Obstacles to Change in Latin America. New York: Oxford University

EDER, GEORGE Press.

1968 Inflation and Development in Latin America: A Case History of Inflation and Stabilization in Bolivia. Ann Arbor: University of Michigan Press.

IMF

1967-68 Staff Reports 1967-1968.

MALLOY, JAMES

1970 Bolivia the Uncompleted Revolution. Pittsburgh: University of Pittsburgh Press.

MALLOY, JAMES and RICHARD THORN

1971 Beyond the Revolution: Bolivia Since 1952. Pittsburgh: University of Pittsburgh Press.

Ministerio de Planificación

1962 Plan Nacional de Desatrollo Económico y Social 1962-1971. La Paz (Bolivia).

1969 Cuentas Nacionales de Bolivia 1950-1969.

PAZ ESTENSSORO, VICTOR

1955 Discursos parlamentarios. La Paz (Bolivia).

Research Institute for the Study of Man

1969 Changing Rural Bolivia. New York.

THORN, RICHARD

1971 "The Economic Transformation." In Malloy and Thorn (eds.), Beyond the Revolution: Bolivia Since 1952. Pittsburgh: University of Pitts-

USAID burgh Press.

1969a Bolivia, Estadísticas Económicas. La Paz (Bolivia).

1969b Monetary and Exchange Developments. La Paz (Bolivia), mimeo. 
Copyright $@ 2002$ EBSCO Publishing 
Copyright of Studies in Comparative International Development is the property of Springer Science \& Business Media B.V. and its content may not be copied or emailed to multiple sites or posted to a listserv without the copyright holder's express written permission. However, users may print, download, or email articles for individual use. 